\title{
Native Insect Pollinators in Apple Orchards under Different Management Practices in the Kashmir Valley
}

\author{
Muzaffar Ahmad Ganie ${ }^{* 1}$, Amit Kumar Pal ${ }^{1}$, Nazeer Ahmad ${ }^{2}$ \\ ${ }^{* 1}$ Institute of Environment and Development Studies, B. U. Jhansi (U.P.) India \\ ${ }^{2}$ Central Institute of Temperate Horticulture, Srinagar, J\&K (India)
}

\section{A R T I C LE IN F O}

\section{Article history:}

Received 30 August 2013

Accepted 19 November 2013

Available online, ISSN: 2148-127X

\section{Keywords:}

Native insect pollinator,

Managed pollination

Apple orchard types

\begin{abstract}
A B S T R A C T
It is now clear that over use of pesticides and intensive management of orchards can lead to drastic declines in apple pollinator abundance and crop failures. During the period of study a grower's survey was conducted to know about knowledge of farmers on native insect pollinators, pollinator management practices, their perceptions of the importance and utility of native pollinators, and their attitudes regarding pesticide application. Despite of having significant knowledge of managed pollination, only few farmers (2\%) adopted supplementary methods of pollination (renting honey bee colonies, hand pollination etc.). In Pulwama, 60\% of farmers had knowledge about native insect pollinators and $40 \%$ did not have any idea of native pollinators and in case of Shopian, the figures were fifty-fifty i.e. $50 \%$ had knowledge about native insect pollinators and $50 \%$ were unaware. During the period of investigation, native insect pollinators were sampled from different apple orchards under different management systems in early spring during apple flowering. A total of 17 species of insect pollinators belonging to 11 families and 3 orders_Hymenoptera, Diptera and Lepidoptera registered their occurrence at all the studied apple orchards of the Kashmir Valley. At all the study sites i.e. apple orchards under different management systems, family Halictidae and Empididae registered their presence as dominant groups. The $\%$ family contribution of the former at different orchard types decreased with increase in the intensity of the management system and the $\%$ family contribution of the later however, showed a direct relationship with the management system found, i.e. the more intense the system, the more abundant was the group. Other groups in general did not show any greater differences in abundances at different sites studied.
\end{abstract}

${ }^{*}$ Corresponding Author:

E-mail: lordslave123@gmail.com

\section{Introduction}

Kashmir has for long been considered the home of apples. Though apple is the major fruit grown in Kashmir, especially in Sopore in north and Shopian and Pulwama in the south, other fruits like cherry, peach, apricots and pears are also grown on a large scale. As a dominant crop of the valley "Apple" proudly represents the fruit industry of Kashmir, representing $98 \%$ of the total fruit production. Fifty million apple boxes are exported from Kashmir to international and domestic fruit markets annually. Kashmir's apple and pear varieties are considered best in the world. While the fruit production in the Valley is around 1.5 to 1.7 Million metric tonnes annually, the growers say Kashmir has a capability to produce 2.5-3.0 Million MT every year. However, anthropogenic changes in management practices in managing apple crop have resulted in substantial reductions in native pollinator diversity and abundance; the deficit in turn can lead to serious damage to entomophilous crops especially the apple crop.

Anthropogenic changes in habitats and climates have resulted in substantial reductions in biodiversity among manyvertebrate taxa and evidence has been accumulating that insect biodiversity is at risk as well (Thomas et al., 2004). There is no doubt that insect pollination is a vital service for agricultural systems. Without insect pollinators, roughly a third of the world's crops would 
flower, only to fade and then lie barren. Pollinators ensure abundant fruits and vegetables. Worldwide an estimated $35 \%$ of crop production is dependent on insect pollination (Klein et al., 2007). According to Tepedino (1980), at least $67 \%$ of flowering plant species depend on pollination by insects, mostly bees.

The non-native European honey bee (Apis melifera) colonies are in decline because of disease (Colony collapse disorder) and other factors (National Research Council, 2007), which makes native pollinators more important to the future of agriculture. This study focuses on native insect pollinators, the most important pollinators in temperate areas.

Native insects provide free pollination services, and are often specialized for foraging on particular flowers, such as squash, berries, or orchard crops (Javorek et al., 2002). This specialization results in more efficient pollination and higher productivity of fruit crops (Greenleaf and Kremen, 2006). Native bees contribute an estimated $\$ 3$ billion worth of crop pollination annually to the U.S. economy (Losey and Vaughan 2006). Protecting, enhancing or providing habitat is the best way to conserve native pollinators (Kremen et al., 2007) and, at the same time, provide pollen and nectar resources that support local honey bees; on farms with sufficient natural habitat, native pollinators can provide all of the pollination for some crops (Winfree et al., 2007).

Any loss in biodiversity is a matter of public concern, but losses of pollinating insects may be particularly troubling because of the potential effects on plant reproduction. Many agricultural crops and natural plant populations are dependent on pollination and often on the services provided by wild, unmanaged, pollinator communities.

There is so much that can be lost by our lack of knowledge on the native pollinators of our area. As of now we have almost no information on where the native pollinators reside, what species are present, and if they depend on a particular environment for their survival, or if they can thrive in several different environments. By not considering this area of concern we stand to lose significantly in economics, food security, and biodiversity.

Keeping these in view, the present investigation is undertaken to address the following objectives:

- Surveys of farmers knowledge about native insect pollinators

- Study of impact of different management practices on insect population on apple crop (IPM, Non-IPM, and wild orchards)

\section{Materials and Methods}

Surveys of growers to assess their familiarity with native pollinator diversity

During the period of study a grower's survey was conducted to know about the farmer's knowledge about native insect pollinators. We have made questionnaires, based upon their basic knowledge on the pollinator management practices, their perceptions of the importance and utility of native pollinators, and their attitudes regarding pesticide application and pollinator conservation. As such 50 apple growers from Pulwama and Shopian district were randomly selected and enquired. This survey provided a tremendous baseline of data on the perceptions and practices of growers in the valley of Kashmir.

\section{Sampling methods}

During the period of investigation, native insect pollinators were sampled in apple orchards under different management systems using Active net collecting and Passive bowl trappingin early spring during apple flowering. As such repeated sampling was performed in three different orchard types (heavily managed, organic, and wild abandoned) in order to assess how management practices affect the abundance and diversity of native insect pollinators.

The sampled apple orchards were first selected on the basis of the frequency of pesticide use and as such divided into Heavily managed (involving very frequent and heavy use of pesticides), Organic (involving very less or no use of chemical pesticides) and Wild( lacking completely any management system)

Site I $\left(33^{\circ} 46^{\prime} \mathrm{N}, 74^{\circ} 49^{\prime} \mathrm{E}, 6275 \mathrm{~m}\right)$ represented apple orchard under IPM.

Site II $\left(33^{\circ} 46^{\prime} \mathrm{N}, 74^{\circ} 49^{\prime} \mathrm{E}, 6240 \mathrm{~m}\right)$ represented apple orchard under Non-IPM.

Site III $\left(33^{\circ} 46^{\prime} \mathrm{N}, 74^{\circ} 49^{\prime} \mathrm{E}, 6254 \mathrm{~m}\right)$ represented Wild orchard.

\section{Active netting}

The first collecting method i.e.; active netting was performed by the participants for thirty minutes two times each sampling day. The first was at $11 \mathrm{am}$ and the other at $3 \mathrm{pm}$. Some pollinating insects have different foraging and behavioral schedules and that is why it was important that the netting be done at different times of the day (Winfree, 2007). After the first fifteen minutes of each netting period the collector switched to other sides of the orchard. After insect pollinators are netted they were euthanized to be identified later in a lab. A small amount of ethyl acetate was infused into plaster of Paris within a jar. Afterwards a crumpled paper towel was placed in the jar to keep the bees from touching the solution and the lids were fastened. When a bee was captured it was placed in the jar, quickly killing it due to the fumes produced by the ethyl acetate.

\section{Bowl trapping}

The next collection method that was used was bowl trapping. This is a standard collection method used in many studies that simply involves filling a bowl with a water and soap solution to collect insects (Winfree, 2007; National Research Council, 2007). The soap serves as a surfactant which reduces the surface tension of the water causing the insect to sink immediately when they land on the water (Cane, 2000). The bowls that were used for this method were Solo brand, 6 oz., disposable bowls of fluorescent blue and yellow (Winfree, 2007). The different colors are to reduce bias in case certain insect pollinators are more attracted to one color than another.There were 16 bowls, 8 of each color.Each bowl was placed $5 \mathrm{~m}$ apart in each orchard i.e; each study site so that each end of the line touches a corner of the plot 
(National Research Council, 2007). The bowls were also placed in random order for color to reduce any sampling bias. The bowls were placed in each area in this manner from $9 \mathrm{am}$ to $5 \mathrm{pm}$ on the same days that the area is being sampled by netting. The samples will then be collected at $5 \mathrm{pm}$ and the bowls removed. The contents of the bowls were sieved to separate the insects which are then stored in $70 \%$ alcohol for later identification. Insect samples were sorted into key taxa in the laboratory and are identified. Once the sampling period is over and all the results have been recorded the data were analyzed.

\section{Results and Discussion}

\section{Grower's survey}

During the period of study a grower's survey was conducted to know about their knowledge on native insect pollinators. We have made questionnaires, which includes basic knowledge on the pollinator management practices, their perceptions of the importance and utility of native pollinators, and their attitudes regarding pesticide application and pollinator conservation. As such 50 apple growers from Pulwama, and Shopian districts were randomly selected and enquired. This survey provided a tremendous baseline of data on the perceptions and practices of growers in the valley of Kashmir.

Almost all the apple growers have adequate knowledge of pollinizers and using mostly Golden Delicious and Chamoora as pollinizer. In addition, some growers were also keeping few trees of Maharaji, Ambri, Kesri and American varieties as pollinizers. The majority of the growers were managing their apple orchards through IPM practices (6 to 10 sprays/season). However, some of the growers from both the areas were using few number of pesticide sprays in their orchards.

From the grower's survey, it was found that all the apple growers of Pulwama and Shopian sprayed two fungicidal sprays during flowering, namely Myclobutanil and Hexaconozole. Growers were spaying first one, during red tip stage and second one, at end of the flowering. Almost all the farmers showed total ignorance regarding the basic process of pollination. The farmers responded differentially regarding awareness about managed pollination and almost all expressed considerable knowledge about managed pollination. Despite of having significant knowledge of managed pollination, only few farmers (2\%) adopted supplementary methods of pollination (renting honey bee colonies, hand pollination etc.). The findings of the growers survey revealed that out of 30 growers surveyed in Pulwama, $60 \%$ had knowledge about native insect pollinators and $40 \%$ did not have any idea of native pollinators and in case of Shopian, the figures were fiftyfifty i.e. $50 \%$ had knowledge about native insect pollinators and $50 \%$ were unaware. Further, the farmers were willing to adopt measures to enhance wild bee pollination.

Impact of different management systems on the diversity and abundance of native insect pollinators

During the period of investigation, native insect pollinators were sampled from different apple orchards under different management systems in early spring during apple flowering. As such repeated sampling was performed in three different orchard types (heavily managed, organic, and wild abandoned) in order to assess how management practices affect the abundance and diversity of native insect pollinators.

During the present study a total of 16 species of insect pollinators belonging to 11 families and 3 orders Hymenoptera, Diptera and Lepidoptera registered their occurrence at all the studied apple orchards of the Kashmir Valley.

The findings of the study revealed that overall, maximum abundance of 175 individuals corresponding to a percent family contribution of 34.93 at all the studied apple orchards was registered by Family Halictidae and least abundance was documented by the family Apidae (3 individuals) contributed by a two species, Euglossa sp. and Xylocopasp. corresponding to a $\%$ family contribution of 0.60 . The variation of abundance in $\%$ family contribution among other intermediate groups followed the pattern (Table 2): Empididae (31.34\%), Muscidae (11.57\%), Bibionidae (8.38\%), Pieridae (5.19\%), Sarcophagidae (2\%), Calliphoridae (2\%), cathophgidae $(1.80 \%)$, Syrphidae $(1.40 \%)$, and Tenthredinidae $(0.80 \%)$.

The species distribution in each of the orders was not uniform. Diptera was the most dominant order composing 9 species and as such accounting for $52.54 \%$ of total species found followed by Hymenoptera accounting 5 Species and Lepidoptera contributing 3 species corresponding to $29.41 \%$ and $17.65 \%$ respectively to the total species contribution reported in the study (Table 3).

At all the study sites i.e. apple orchards under different management systems, Family Halictidae and Empididae registered their presence as dominant groups. The $\%$ family contribution of the former at different orchard types decreased with increase in the intensity of the management system and the \% family contribution of the later however, showed a direct relationship with the management system found, i.e. the more intense the system, the more abundant was the group. Other groups in general did not show any greater differences in abundances at different sites studied (Table 4).

Diversity indices for the apple orchards under different management systems

To estimate the species diversity and relative abundance, four diversity indices viz. richness, evenness, Shannon-Weiner index, Simpson index were calculated (Table 5).

\section{Richness}

The number of species per sample or the number of species in a community is referred to as species richness. The more species present in a sample or a community, the 'richer' is the sample or the community. For the different orchards, the values calculated were 11(IPM), 14 (NonIPM) and 16 (Wild), showing more richness of species in wild orchards than the other two apple orchards.

\section{Evenness}

Evenness is a measure of the relative abundance of the different species making up the richness of an area. In other words, species evenness refers to how close in numbers each species in an environment are. The 
calculated values of evenness index for different orchard types were 0.76 (IPM), 0.73 (Non- IPM) and 0.74(Wild) meaning that the species distribution is more even in intensively managed orchards (IPM) than the other two orchard types(Non-IPM and Wild), which opposes the general trend of diversity change.

\section{Shannon-Wiener Index}

Shannon Weiner index values for the apple orchards under different management systems were 1.833 (IPM), 1.919 (Non- IPM) and 2.041 (Wild) which implies that the diversity decreases with increase in intensity of management practice.

\section{Simpson index}

Simpson's Index is one of the simplest calculations that takes into account species evenness within a community. Simpson's Index (D) is dependent on the number of species and their relative dominance. The calculated Simpson index values were 0.786(IPM), 0.794 (Non- IPM) and 0.809 (Wild). The Simpson index varied in accordance with the Shannon-Weiner index, showing the same trend of diversity change in the apple orchards studied.

Table 1. Overall contribution of various taxa collected from the three orchard types.

\begin{tabular}{|c|c|c|c|c|}
\hline Name of taxa & $O^{I}$ & $I P M^{2}$ & Non-IPM ${ }^{3}$ & Wild $^{4}$ \\
\hline $\begin{array}{l}\text { Order: Hymenoptera } \\
\text { Family: Halictidae }\end{array}$ & & & & \\
\hline Lasioglossoma himalayense & 131 & 27 & 32 & 72 \\
\hline $\begin{array}{l}\text { Lasioglossomanursie } \\
\text { Family: Apidae }\end{array}$ & 44 & 8 & 10 & 26 \\
\hline Euglossa sp. & 2 & 0 & 0 & 2 \\
\hline $\begin{array}{l}\text { Xylocopa } s p . \\
\text { Tenthredinidae }\end{array}$ & 1 & 0 & 0 & 1 \\
\hline $\begin{array}{l}\text { Athalia } s p . \\
\text { Order: Lepidoptera } \\
\text { Family: Pieridae }\end{array}$ & 4 & 1 & 3 & 0 \\
\hline Pieris brassicae & 20 & 4 & 6 & 10 \\
\hline Colias fieldii & 3 & 0 & 1 & 2 \\
\hline Colias philodice & 3 & 0 & 1 & 2 \\
\hline $\begin{array}{l}\text { Order: Diptera } \\
\text { Family: Syrphidae }\end{array}$ & & & & \\
\hline Syrphu ssp. & 4 & 0 & 1 & 3 \\
\hline $\begin{array}{l}\text { Echium sp. } \\
\text { Muscidae }\end{array}$ & 3 & 0 & 0 & 3 \\
\hline Musca domestica & 41 & 13 & 11 & 17 \\
\hline $\begin{array}{l}\text { Ophyra sp. } \\
\text { Sarcophagidae }\end{array}$ & 17 & 4 & 6 & 7 \\
\hline $\begin{array}{l}\text { Sarcophaga sp. } \\
\text { Calliphoridae }\end{array}$ & 10 & 1 & 3 & 6 \\
\hline $\begin{array}{l}\text { Calliphora sp. } \\
\text { Bibionidae }\end{array}$ & 10 & 1 & 1 & 8 \\
\hline $\begin{array}{l}\text { Bibio sp. } \\
\text { Scathophagidae }\end{array}$ & 42 & 10 & 24 & 8 \\
\hline $\begin{array}{l}\text { Scathophagia } s p . \\
\text { Family: Empididae }\end{array}$ & 9 & 3 & 2 & 4 \\
\hline Unidentified sp. & 157 & 39 & 56 & 62 \\
\hline Total & 501 & 111 & 157 & 233 \\
\hline
\end{tabular}

Table 2. Showing Overall percent contribution of various families collected at all the three orchard types

\begin{tabular}{l|cc}
\hline \multicolumn{1}{|c|}{ Name of Family } & Overall family contribution & Overall percent Contribution \\
\hline Halictidae & 175 & 34.93 \\
Empididae & 157 & 31.34 \\
Muscidae & 58 & 11.57 \\
Bibionidae & 42 & 8.38 \\
Pieridae & 26 & 5.19 \\
Sarcophagidae & 10 & 2 \\
Calliphoridae & 10 & 2 \\
Scathophagidae & 9 & 1.80 \\
Syrphidae & 7 & 1.40 \\
Tenthredinidae & 4 & 0.80 \\
Apidae & 3 & 0.60 \\
\hline
\end{tabular}




\title{
Overall percent family Contribution
}

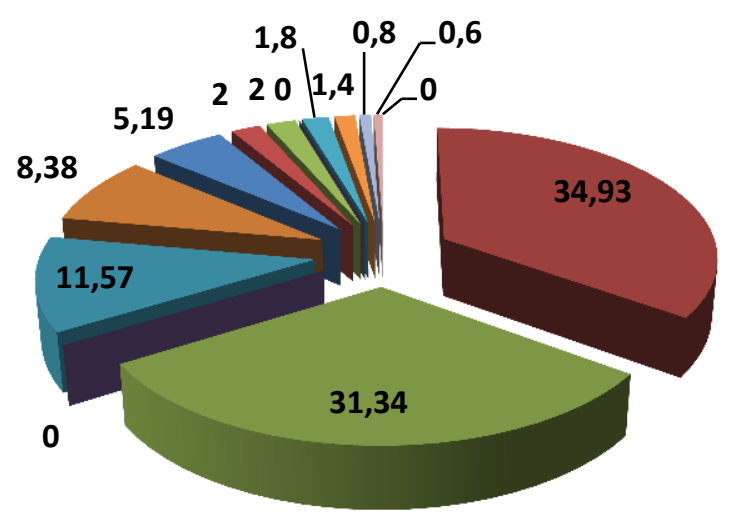

\author{
- Halictidae \\ Empididae \\ Muscidae \\ Bibionidae \\ - Pieridae \\ - Sarcophagidae \\ - Calliphoridae \\ - Scathophagidae \\ - Syrphidae \\ - Tenthredinidae
}

Fig 1. Showing Overall percent contribution of various families collected at all the three orchard types.

\section{Overall family contribution}

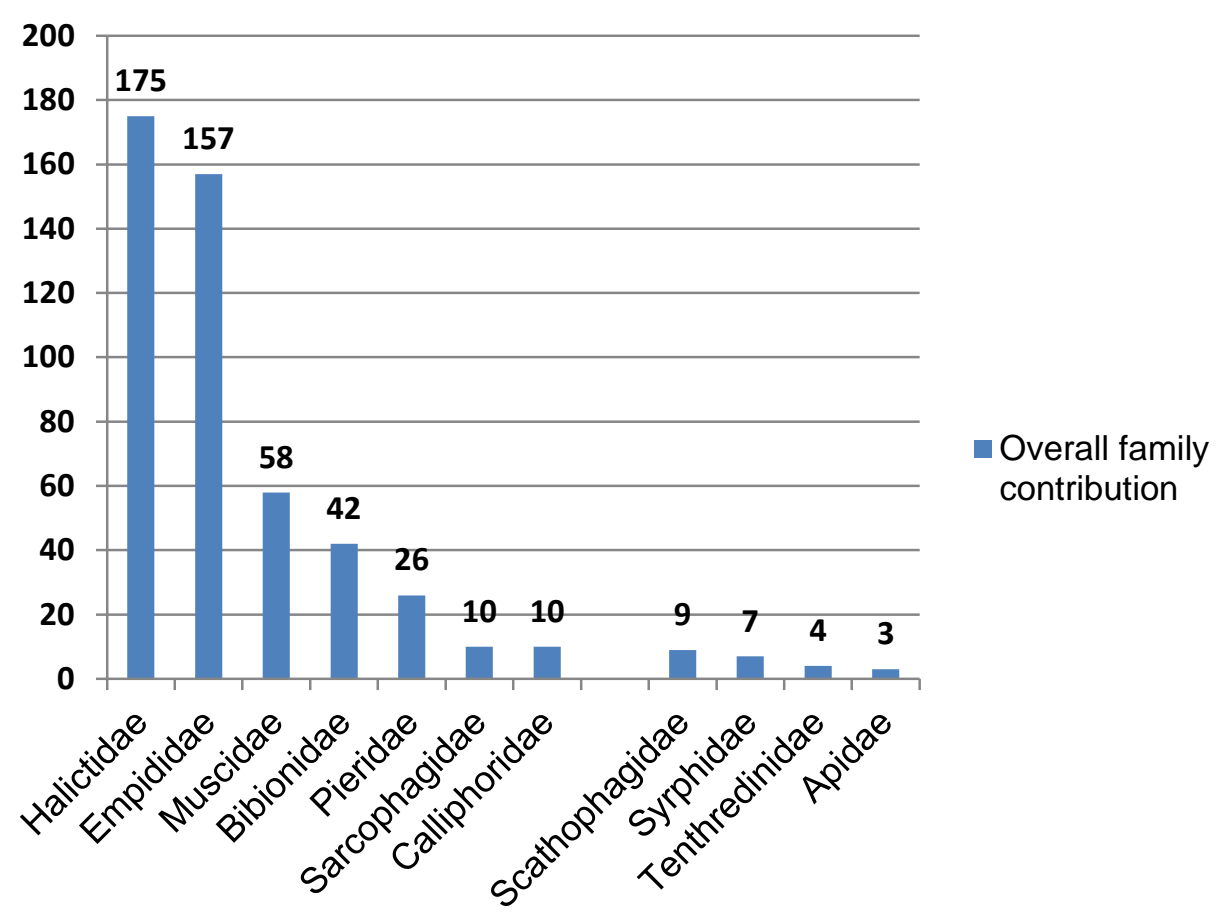

Fig 2. Diagrammatic representation of overall percent contribution of various families collected at all the three orchard types

\section{Grower's survey}

The findings of the growers survey revealed that majority of the growers managed their apple orchards through extensive management practices (IPM and NonIPM) and make excessive use of pesticides. The growers had adequate knowledge of pollinizers and native and managed pollinators but at the same time were totally unaware about the basic process of pollination and also were not adopting any supplementary methods to enhance pollination but showed considerable will to adopt practices that would improve the pollination service provided by native insect pollinators. Similar findings were also registered by Jasra et al. (2001), when they were studying apple pollination problems in Balochistan, Pakistan. The results indicated that majority of the farmers $(72 \%)$ had no knowledge of pollination. overall $49 \%$ respondents were regularly using pesticides and 79 $\%$ perceived that insect population was decreasing which was in conformity of our findings. Partap et al. (2001) also confirmed the same findings who reported that despite of having knowledge of pollination and managed pollination, people in China did not adopt any supplementary methods to enhance native insect 
pollinators. Park et al. (2010) conducted a grower survey in NY and confirmed that majority of the growers employed a variety of pest management regimes; with majority using IPM which implies that the findings were also in conformity with our survey results.

Impact of different management systems on the diversity and abundance of native insect pollinators

At all the study sites i.e. apple orchards under different management systems, Family Halictidae and Empididae registered their presence as dominant groups. The $\%$ family contribution of the former at different orchard types decreased with increase in the intensity of the management system and the $\%$ family contribution of the later however, showed a direct relationship with the management system found, i.e. the more intense the system, the more abundant was the group. Other groups in general did not show any greater differences in abundances at different sites studied. Overall, the study revealed that the wild orchard was the most diverse site compared to the other sites and registered highest percentage of abundances of the representative species. The calculated value of Shannon weiner index at this site was 2.0413 and the site was found to possess 16 species in its community structure. These findings can be correlated with that of Kessler et al. (2009) and Hogsden and Hutchinson (2004), who confirmed that moderate land use maximizes the richness and abundance of pollinators. The variation against the general trend i.e. some pollinators exhibited higher dominances at intensively managed habitats (Here orchard types under IPM and Non-IPM) can be attributed to the fact that low level anthropogenic landuse increase the heterogeneity of habitats and resources, thus increasing niche diversity as was reported by Tewset al.(2004). The findings of Cunningham (2000) also supported our findings and documented that landuse intensification and habitat fragmentation affect pollinator diversity and abundance. Moron et al. (2011) also highlighted a negative relationship between pollution and populations of wild bees and added that increasing wild bee richness in highly contaminated areas is at risk and need conservation. The findings as such support our research results. Similar findings were aso reported by Pauw, A. (2007) who documented an important fact regarding collapse of a pollination web in small conservation areas located in the Cape Floral Region. The studies also revealed anthropogenic declines detectable against this background of naturally occurring variation. Moreover, Order Lepidoptera was represented by three species Pierisbrassicae, Coliasfieldi and Colias Philodice contributing a total abundance of 26 individuals at all the orchard types, but a major contribution was provided by the species in wild orchards. This can be supported by the works of Hodgson et al. (2010) who concluded that organic farms supported a higher density of butterflies than conventional farms, but a lower density than reserves.
Table 3. Species composition of various taxa collected from all apple orchards of Kashmir valley under different management practices

\begin{tabular}{l|cc}
\hline Order & No. of species & $\begin{array}{c}\text { Percent species } \\
\text { contribution }\end{array}$ \\
\hline Hymenoptera & 5 & 29.41 \\
Lepidoptera & 3 & 17.65 \\
Diptera & 9 & 52.94 \\
\hline
\end{tabular}

\section{Percent species contribution}

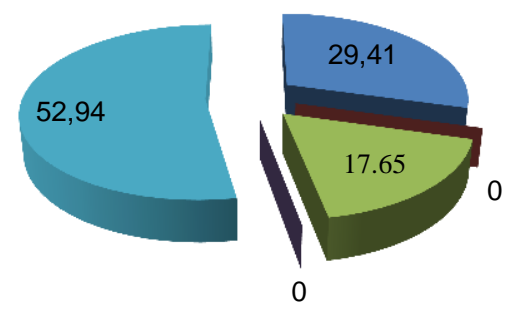

Hymenoptera

- Lepidoptera

- Diptera

Fig 3: Diagrammatic representation of percent Species composition of various taxa from apple orchards under different management practices.

Table 4. Percent Family contribution of various taxa at different orchard types:

\begin{tabular}{l|rcr}
\hline \multirow{2}{*}{ Name of taxa } & \multicolumn{3}{|c}{ Percent family contribution } \\
\cline { 2 - 4 } Halictidae & $\begin{array}{c}\text { IPM apple } \\
\text { orchard }\end{array}$ & $\begin{array}{c}\text { Non-IPM } \\
\text { apple orchard }\end{array}$ & $\begin{array}{c}\text { Wild apple } \\
\text { orchard }\end{array}$ \\
Apidae & 31.5 & 26.8 & 42.1 \\
Tenthredinidae & 0 & 0 & 1.3 \\
Pieridae & 0.9 & 1.9 & 0 \\
Syrphidae & 3.6 & 5 & 5.9 \\
Muscidae & 0 & 0.6 & 2.6 \\
Sarcophagidae & 15.3 & 10.8 & 10.3 \\
Calliphoridae & 0.9 & 1.9 & 2.5 \\
Bibionidae & 0.9 & 0.6 & 3.4 \\
Scathophagidae & 9 & 15.3 & 3.4 \\
Empididae & 2.70 & 1.3 & 1.8 \\
\hline
\end{tabular}

Percent family contribution IPM orchard

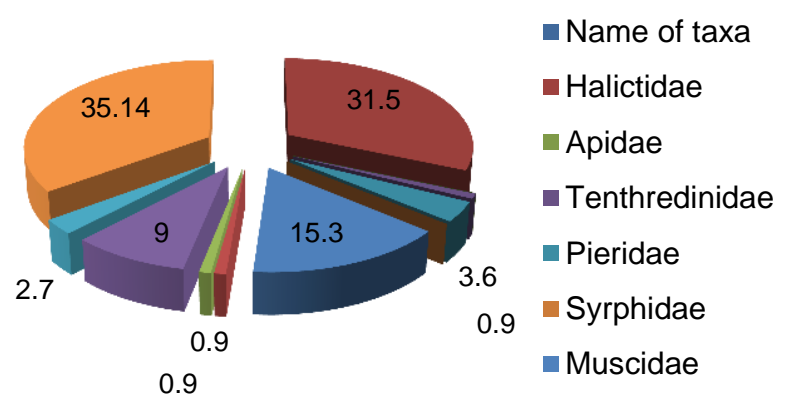

Fig 4. Percent Family contribution of various taxa at IPM apple orchard 
Table 5. Calculated values of diversity indices for apple orchards under different management practices of the Kashmir Valley:

\begin{tabular}{l|ccc}
\hline $\begin{array}{l}\text { Diversity } \\
\text { index }\end{array}$ & IPM & Non-IPM & Wild \\
\hline $\begin{array}{l}\text { Shannon- } \\
\text { Weiner index }\end{array}$ & 1.833 & 1.919 & 2.041 \\
$\begin{array}{l}\text { Simpson } \\
\text { index } \\
\begin{array}{l}\text { Species } \\
\text { richness } \\
\text { Evenness } \\
\text { index }\end{array}\end{array}$ & 0.787 & 0.795 & 0.809 \\
\hline
\end{tabular}

Percent family contribution Non-IPM orchard

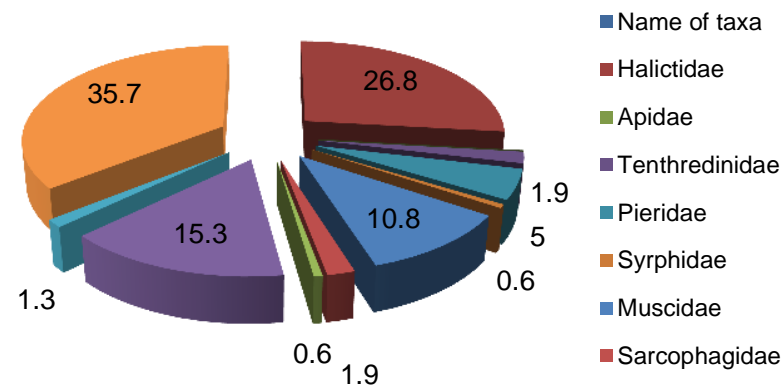

Fig 5. Percent Family contribution of various taxa at NonIPM apple orchard

\section{Percent family contribution Wild orchard}

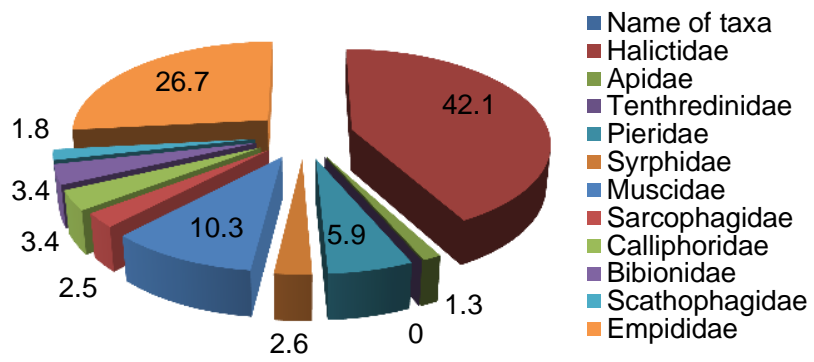

Fig 6. Percent Family contribution of various taxa at wild apple orchard

As declining populations of honey bees are reported, it is essential that we identify promising native pollinators to fill this crucial need for insect pollination. Apples provide an ideal system because there are already many native pollinator species that could be highly effective pollinators. To assess the impact of different management systems on the abundance and diversity of the native insect pollinators, three different types of apple orchards in the Kashmir Valley (1) heavily managed orchards in which pesticides are used, (2) organically managed orchards in which pesticide applications are kept to a minimum, and (3) wild orchards where pesticides are not used were selected and studied to identify the promising native fauna which may be playing a key role in apple pollination.
There is a variety of native pollinators present in apple orchards in the Valley of Kashmir; however, the most numerous native pollinators in apple orchards were reported from the family Halictidae, and the genus Lasioglossum, being found in high numbers. It is important to maintain a natural habitat that is suitable for Lasioglossum and other native pollinators, ensuring that these important native bees are present in an apple orchard and will contribute to fruit set. Specifically, there needs a shift from extensive management systems like IPM and Non- IPM in apple orchards to organic farming systems. This will reduce the danger or threat the native pollinators face while encountering different pesticides.

\section{Acknowledgements}

As a matter of proud and pleasure I express my profound gratitude and thanks to my research supervisor "Dr. A. K. Pal" Assistant Professor, Institute of Environment and Development Studies, B. U. Jhansi and Co Supervisor, Dr. (Prof.) Nazeer Ahmad, Director, Central Institute of Temperate Horticulture, Srinagar, $\mathrm{J} \& \mathrm{~K}$ for their valuable and dignified guidance, encouragement, suggestions and positive critics which played the main role in the completion of my work.

\section{References}

Cunningham SA. 2000. Depressed pollination in habitat fragments causes low fruit set. Philosophical Transactions of the Royal Society of London Series B-Biol. Sc., 267: 11491152.

Greenleaf SS, Kremen C. 2006. Wild bee species increase tomato production and respond differently to surrounding land use in Northern California. Biol. Conser., 133: 81-87.

Hodgson JA, Kunin WE, Thomas CD, Benton TG, Gabriel D. 2010. Comparing organic farming and land sparing: optimizing yield and butterfly populations at a landscape scale.Ecol. Lett. 13:1358-67.

Hogsden KL, Hutchinson T. 2004. Butterfly assemblages along a human disturbance gradient in Ontario, Canada.Can. J. Zool. 82:739-48.

Jasra AW, Ashfaq S, Kasi MA. 2001. Apple Pollination Problems in Balochistan, Pakistan.Int. J. Agri. Biol., 3: 210213.

Javorek SK, Mackenzie KE, Vander Kloet SP. 2002. Comparative Pollination Effectiveness Among Bees (Hymenoptera: Apoidea) on Lowbush Blueberry (Ericaceae: Vacciniumangustifolium). Annals of the Entomological Society of America 95: 345-351.

Kessler K, Abrahamczyk S, Bos M, Buchori D, Putra DD, Gradstein SR, Höhn P, Kluge J, Orend F, Pitopang R, Saleh S, Schulze CH, Sporn SG, Dewenter IS, Tjitrosoedirdjo SS, Tscharntke T. 2009. Alpha and beta diversity of plants and animals along a tropical land-use gradient. Ecological Applications 19:2142-2156. http://dx.doi.org/10.1890/081074.1

Klein AM, Vaissiere BE, Cane JH, Steffan-Dewenter I, Cunningham SA, Kremen C, Tscharntke T. 2007. Importance of pollinators in changinglandscapes for world crops.Proc R SocLond Biol., 274: 303-313.

Kremen C, Williams NM, Aizen MA, Gemmill-Herren B, LeBuhn G, Minckley R, Packer L, Potts SG, Roulston T, Steffan-Dewenter I, Vázquez DP, Winfree R, Adams L, Crone EE, Greenleaf SS, Keitt TH, Klein AM, Regetz J, Ricketts TH. 2007. Pollination and other ecosystem services produced by mobile organisms: a conceptual framework for the effects of land-use change. Ecol Lett. 10: 299-314. 
Losey JE, Vaughan M. 2006.The economic value of ecological services provided by insects.Biosc.56: 311-323.

Moron' D, Grzes' IM, Sko'rka P, Szentgyorgyi H, Laskowski R, Potts SG, Woyciechowski M. 2011. Abundance and diversity of wild bees along gradients of heavy metal pollution. J. App. Ecol., 10: 1365-2664.

National Research Council 2007. Committee on the Status of Pollinators in North America, and National Academies Press. Status of pollinators in North America. Washington, D.C.: National Academies Press.

Park MG, Orr MC, Danforth BN. 2010. The role of native bees in apple pollination. New York State Fruit Quarterly 18: 2125.

Partap UMA, Partap TEJ, Yonghua HE. 2001. Pollination failure in apple crop and farmers' management strategies in the Hengduanmoutains, China.Acta Hort. (ISHS)561: 225230.
Pauw A. 2007. Collapse of a pollination web in small conservation areas. Ecology, 88: 1759-1769.

Tepedino V. 1980. The importance of bees and other insect pollinators in maintaining floral species composition. Great Basin Naturalist Memoirs.

Tews J, Brose U, Grimm V, Tielbörger K, Wichmann MC, Schwager M, Jeltsch F. 2004. Animal species diversity driven by habitat heterogeneity/diversity: the importance of keystone structures. J. Biogeogr. 31:79-92.

Thomas CD, Cameron A, Green RE, Bakkenes M, Beaumont LJ, Collingham YC, Erasmus BFN, Siqueira MF, Grainger A, Hannah L, Hughes L, Huntley B, Van Jaarsveld AS, Midgley GF, Miles L, Ortega-Huerta MA, Peterson AT, Phillips OL, Williams SE. 2004. Extinction risk from climate change. Nature427:145-148.

Winfree R, Williams NM, Dushoff J, Kremen C. 2007. Native bees provide insurance against ongoing honey bee losses. Ecol.Letters.10:1105-1113. 